\title{
Nutrient depletion and particulate matter near the ice-edge in the Weddell Sea
}

\author{
Fiz F. Pérez, Francisco G. Figueiras, Aida F. Ríos \\ Instituto de Investigaciones Marinas de Vigo (CSIC), Eduardo Cabello, 6, E-36208 Vigo, Spain
}

\begin{abstract}
The region between Elephant Island and the South Orkney Islands $\left(53.5^{\circ} \mathrm{S}, 46.5^{\circ} \mathrm{W}\right)$ was occupied by Winter Weddell Sea water and a thick layer of summer and surface modified Weddell Water. High correlations between nutrients (nitrate, total inorganic carbon, silicate) and oxygen with salinity were found in the upper $150 \mathrm{~m}$ near the ice-edge. Nutrient depletion was calculated and correlated with the melting ice processes. When $1 \mathrm{~m}$ of ice melts, the average amount of total carbonate and nutrients removed is equivalent to a production of $33 \mathrm{~g} \mathrm{C} \mathrm{m}^{-2} \mathrm{yr}^{-1}$. Increases of oxygen were detected with high rates of nutrient and carbon depletion. However, significant oxygen losses in the melting water body were estimated from the conservative 'NO' parameter. The amount of nutrients removed during pack-ice melting was about 3 times higher than that taken up in the water column. Analyses of particulate material in the ice samples showed similar C:N ratios to those estimated by the decrease of nutrients in the water column.
\end{abstract}

KEY WORDS: Ice-edge - Nutrient depletion - Redfield ratios - Particulate matter - Primary production

\section{INTRODUCTION}

It is well known that an intense, large-scale upwelling south of the Antarctic Convergence gives rise to high nutrient concentrations in the euphotic layer (Tréguer \& Jacques 1986, 1992, Bennekom et al. 1989). This upwelling is known to generate water masses with low stability (Deacon \& Moorey 1975, Deacon \& Foster 1977), where horizontal and vertical mixing rates are too fast to maintain sizable phytoplankton populations able to take up these vast amounts of nutrients (Sakshaug \& Holm-Hansen 1984).

Small-scale convergences near the ice-edge may become stabilized by the accumulation of melt-water, and give rise to areas with high chlorophyll concentrations. As seawater density is controlled mainly by salinity at low temperatures, ice melting provides a mesoscale stability where a moderate biomass of phytoplankton develops. Thus, in summer, stability can be generated mainly by a decrease in surface salinity rather than a rise in temperature. In a companion paper (Pérez et al. 1994), the dynamics of water masses affected by the marginal ice-zone were described, as well as the different levels of stratifica- tion and associated concentrations of nutrients and chlorophyll. Similar physical distributions have been described by several authors in Antarctic seas (ElSayed \& Taguchi 1981, Sakshaug \& Holm-Hansen 1984, Nelson et al. 1989), and also in the Bering Sea (Alexander \& Niebauer 1981).

High nutrient levels and surface light promote elevated concentrations of chlorophyll in cultures maintained on board (Baar et al. 1989). In contrast, it is difficult to measure chlorophyll values greater than $6 \mu \mathrm{g}$ $1^{-1}$ in the sea, although nutrient consumption could theoretically produce chlorophyll concentrations greater than $25 \mathrm{\mu g} \mathrm{l}^{-1}$ (Bennekom et al. 1989), or even 40 to $80 \mathrm{\mu g} \mathrm{l}^{-1}$ (Sakshaug \& Holm-Hansen 1984).

Microalgal concentrations near frazil ice may increase primary production in the pack-ice. Garrison et al. (1989) showed that frazil ice can contain 2 to 4 times more organisms than the underlying water. Smith \& Nelson (1986) calculated that overall pelagic primary productivity for the entire Southern Ocean would be increased by at least $60 \%$ if the effects of the receding ice-edge were taken into account.

Although some of the organic carbon produced by the phytoplankton is lost by sinking, grazing and 


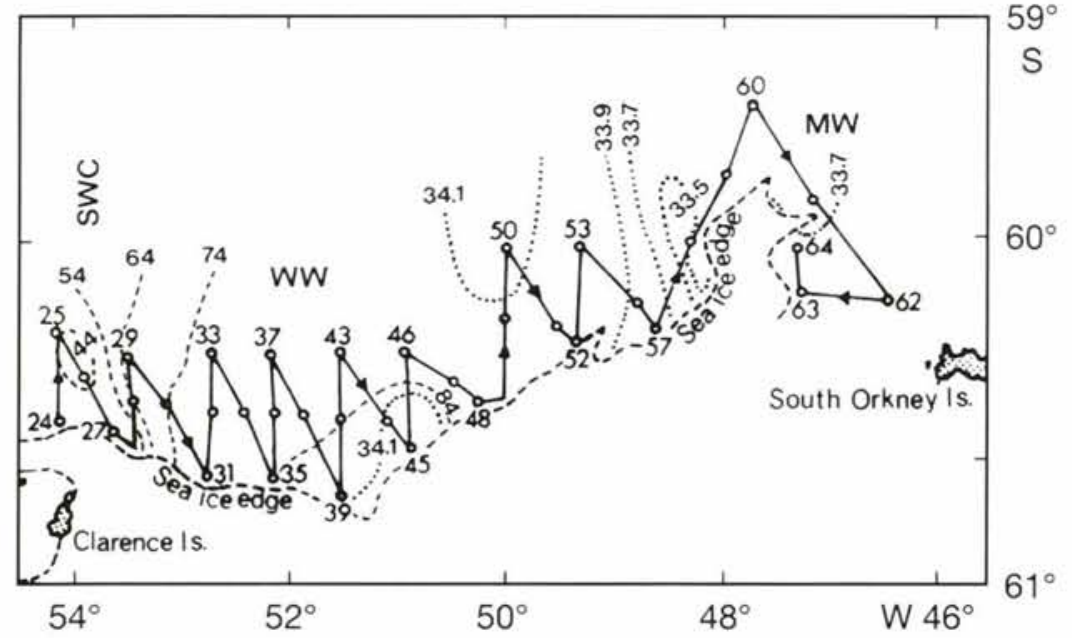

Fig. 1. Position of stations and the sea ice-edge during the cruise BIOMASS IV. $(\cdots)$ Silicate distributions nearby the Scotia-Weddell Confluence; $(\cdots)$ salinity distributions in the eastern front

export from the area (El-Sayed 1984, Baar et al. 1989, Jacques \& Panouse 1989), oxygen, nutrients and total inorganic carbon (TIC) remained in the water as a record of the photosynthesis from an earlier period. The aims of this study are (1) to study the relationship between nutrient depletion, oxygen production and salinity decreases and (2) to estimate the production of organic carbon due to ice melting from the amount of nutrients removed from the water column.

\section{MATERIAL AND METHODS}

An oceanographic cruise (BIOMASS IV) was carried out between December 29, 1988 and January 9, 1989, on board RV 'Professor Siedlecki'. Measurements of water temperature, salinity and dissolved oxygen were conducted at 29 stations located in a $40 \mathrm{~km}$ zone off the ice-edge between Elephant $\left(54.5^{\circ} \mathrm{W}\right)$ and South Orkney Islands $\left(46.5^{\circ} \mathrm{W}\right)$ (Fig. 1). Profiles of conductivity, temperature and dissolved oxygen were obtained with a Neil-Brown CTD- $\mathrm{O}_{2}$ probe between 0 and $1000 \mathrm{~m}$. The CTD probe was calibrated with reversing thermometers (Gohla-Kiel, Germany) and a Plessey Model $6230 \mathrm{~N}$ Laboratory salinometer. The dissolved oxygen sensor was calibrated using the modified Winkler method (Carritt \& Carpenter 1966).

Water samples were collected at $0,10,20,30,40,50$, 75,100 and $150 \mathrm{~m}$ and analyzed for silicate, nitrate,

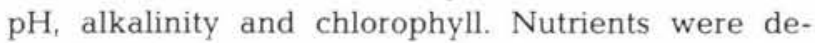
termined by colorimetric methods, using a Technicon autoanalyzer. For silicates, a modified Grasshoff method was used, in which an isomer of silicomolybdenic acid is reduced with ascorbic acid (Hansen \&
Grasshoff 1983). Nitrate was determined after reduction to nitrite in a $\mathrm{Cd}-\mathrm{Cu}$ column (Mouriño \& Fraga 1985).

A 'Metrohm' E-654 pH meter, with an Orion 81-04 electrode calibrated with 7.413 NBS buffer, was used to determine $\mathrm{pH}$. Temperature was measured in parallel with a Pt-100 resistance thermometer which allows temperature correction of $\mathrm{pH}$. All $\mathrm{pH}$ values refer to $15^{\circ} \mathrm{C}\left(\mathrm{pH}_{15}\right)$ (Pérez \& Fraga 1987a). An automatic titration system 'Metrohm' E-425 was used to measure alkalinity with $\mathrm{HCl}$ to final $\mathrm{pH}$ 4.44 (Pérez \& Fraga 1987b). TIC was calculated using the equations of the carbonic system and the constants determined by Mehrbach et al. (1973).

Fluorescence was measured with a Turner Design $1000 \mathrm{R}$ fluorometer. Samples were allowed to adapt to darkness at laboratory temperature for $20 \mathrm{~min}$ (Falkowski \& Kiefer 1985). Two types of measurements were made: in vivo fluorescence and maximum fluorescence after adding $\operatorname{DCMU}\left(F_{\mathrm{d}}\right)$. Chlorophyll a was estimated from $F_{\mathrm{d}}$ readings. For calibration, $100 \mathrm{ml}$ of water was filtered through Whatman GF/F filters and the chlorophyll extracted with $90 \%$ acetone. Fluorescence of the extracts was measured with the same instrument. Chlorophyll concentrations were corrected for phaeopigments (Yentsch \& Menzel 1963, Holm-Hansen et al. 1965). The coefficient of determination obtained for the relationship between the calculated chlorophyll values and the $F_{\mathrm{d}}$ reading was $0.98(\mathrm{n}=20)$.

For the analysis of particulate carbon and nitrogen, 21 of water was filtered through Whatman GF/F $25 \mathrm{~mm}$ diameter filters. The analyses were carried out with a Perkin Elmer 240 Elemental Analyser, according to Fraga (1976). Blanks for $\mathrm{C}$ and $\mathrm{N}$ were 0.8 and $0.06 \mu \mathrm{mol}$, respectively. Reproducibility of the method was $\pm 0.1 \mu \mathrm{M}$ for $\mathrm{C}$ and $\pm 0.02 \mu \mathrm{M}$ for $\mathrm{N}$.

\section{RESULTS}

\section{Nutrient depletion}

Pérez et al. (1994) described the dynamic pattern due to mesoscale physical structures in the region. They showed divergent areas $\left(51\right.$ to $\left.53.5^{\circ} \mathrm{W}\right)$ with low stability water column where the highest salinity and silicate concentrations were found (Fig. 1). The physico-chemical characteristics of these bodies of water corresponded to Weddell Water (WW). In the 
Table 1. Representative characteristics of Weddell Water (WW) obtained from samples taken at $150 \mathrm{~m}$ at 30 stations. S: salinity; $\mathrm{T}$; temperature; TIC: total inorganic carbon; Alk.; alkalinity; $\mathrm{pH}_{15}$ : temperature-corrected $\mathrm{pH}$, all values refer to $15^{\circ} \mathrm{C}$

\begin{tabular}{|c|c|c|c|c|c|c|c|c|c|c|c|}
\hline & $\mathrm{S}$ & $\mathrm{T}$ & $\mathrm{O}_{2}$ & $\mathrm{NO}_{3}$ & $\mathrm{SiO}_{4}$ & TIC & 'NO' & ${ }^{\prime} \mathrm{CAO}^{\prime}$ & 'SiO' & Alk, & $\mathrm{pH}_{15}$ \\
\hline $\bar{x}$ & 34.39 & -1.1 & 6.31 & 32.2 & 89 & 1097 & 613 & 1763 & 781 & 2338 & 7.85 \\
\hline$\sigma$ & 0.04 & 0.3 & 0.15 & 0.5 & 3 & 10 & 5 & 14 & 14 & 4 & 0.01 \\
\hline
\end{tabular}

western part of the study area, the Scotia-Weddell Confluence (SWC) was detected by the strong gradient of silicate. In the eastern part, a lens of low salinity water (MW) generated by pack-ice melting was found. MW is formed from WW which has been modified by
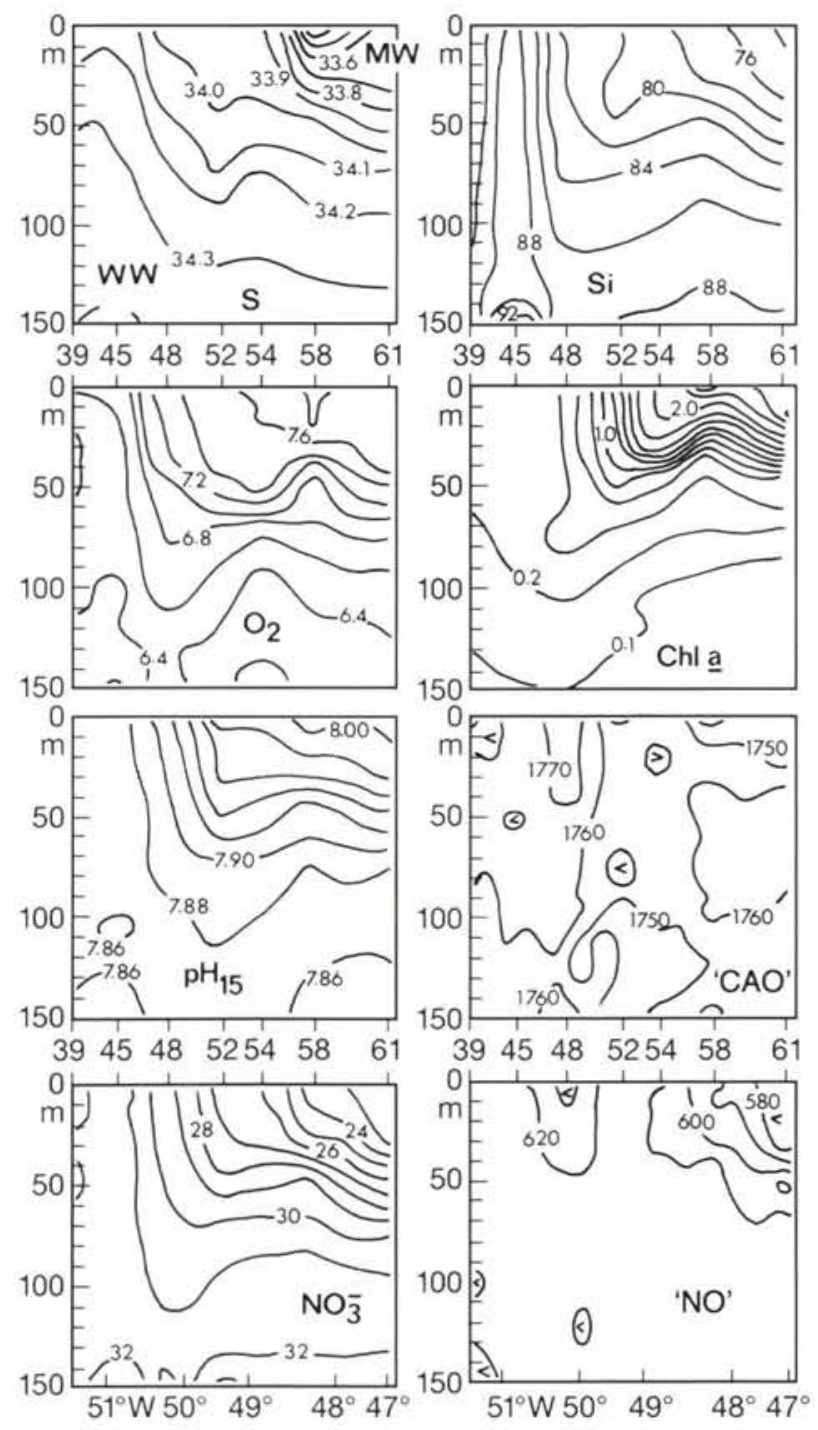

Fig. 2. Vertical profiles of salinity $(\%)$, silicates $\left(\mu \mathrm{mol} \mathrm{kg}{ }^{-1}\right)$, oxygen $\left(\mathrm{ml} \mathrm{1}^{-1}\right)$, chlorophyll a $\left(\mu \mathrm{g}^{-1}\right), \mathrm{pH}_{15}, \mathrm{CAO}^{\prime}(\mu \mathrm{mol}$ $\left.\mathrm{kg}^{-1}\right)$, nitrates $\left(\mu \mathrm{mol} \mathrm{kg}{ }^{-1}\right)$ and 'NO' $\left(\mu \mathrm{mol} \mathrm{kg}^{-1}\right)$ in the transect close to the ice-edge heating and mixing with melting ice, and was characterized by salinity values lower than 34 psu. The MW forms a saline front with the WW along $49^{\circ} \mathrm{W}$.

In this study we consider only the bodies of water of Weddell Sea origin situated to the southeast (SWC), close to the ice-edge ( 47 to $53^{\circ} \mathrm{W}$ ), and characterised by high silicate concentrations (Fig. 1). The sharpest gradients were found along the ice-edge. Thus, the transect crossing the front separating MW from WW was selected to describe the hydrographic pattern. The salinity distribution along this transect (Fig. 2) shows the vertical spreading of MW into WW. The maximum influence of $\mathrm{MW}$ was located along $48^{\circ} \mathrm{W}$, extending down to $50 \mathrm{~m}$. WW dominated the areas of greater homogeneity and the layer situated below MW.

The distributions of chemical variables were similar to that of salinity. Low values of nitrate and silicate and high values of $\mathrm{pH}$ and $\mathrm{O}_{2}$ were found in $\mathrm{MW}$, whereas high values of nitrate and silicate and low $\mathrm{pH}$ and oxygen were associated with higher proportions of WW. The low variability of the physico-chemical properties observed below $100 \mathrm{~m}$ enables us to characterize the properties of WW by averaging the samples taken at $150 \mathrm{~m}$ in each station (Table 1). Bennekom et al. (1989) showed similar characteristics for 'Winter Water' in the Weddell Sea and for the 'Under Ice Water Layer'.

A clear correlation was apparent between salinity and nutrients, pH and oxygen. The percentage of variance explained by the linear regression of the different nutrients and oxygen against salinity was greater than $70 \%$, reaching almost $80 \%$ with nitrate and TIC (Table 2). Correlation was still stronger between $\mathrm{pH}_{15}$ and $\mathrm{NO}_{3}(\mathrm{r}=0.92)$. This correlation structure indicates that mixing of WW with melt-water is the major factor affecting the distribution of nutrients observed in this region, i.e. they behave in a quasi-conservative way, and therefore the concentration of nutrients in any sample could be calculated from the ratio of WW and MW.

Using the coefficients $R_{C}$ and $R_{N}$ shown in Table 2 and the N:P ratio obtained by linear regression of the data published by Alvarez (1989) in the Orkney Islands $\left(\mathrm{r}^{2}=0.92\right.$ and $\left.\mathrm{N}: \mathrm{P}=15.1 \pm 0.1\right)$, the ratio $\mathrm{O}_{2}: \mathrm{C}: \mathrm{N}: \mathrm{P}$ was determined as 142:111:15:1, which corresponds to the oxidation of organic material of the empirical formula $\mathrm{C}_{113} \mathrm{H}_{183} \mathrm{O}_{69} \mathrm{~N}_{15} \mathrm{P}$. These stoichiometric equations are 
Table 2. Coefficients of the linear statistical fit of oxygen, nitrates, silicates, total carbon $\left(\mu \mathrm{mol} \mathrm{kg}{ }^{-1}\right), \mathrm{pH}_{15}$ and chlorophyll against salinity. Total inorganic carbon (TIC) corrected according to Ríos et al. (1989) for alkalinity variations due to precipitation or redissolution of calcium carbonate. The slopes of linear regressions between oxygen and nutrients are shown by $\mathrm{R}_{y}$

\begin{tabular}{|lccc|}
\hline \multicolumn{1}{|c}{$Y$} & Slope & $\mathrm{r}^{2}$ & $\mathrm{R}_{y}=-\left(\mathrm{std} \mathrm{O}_{2}\right) /($ std $Y)$ \\
\hline $\mathrm{O}_{2}$ & -103 & 0.72 & \\
$\mathrm{NO}_{3}$ & 11.5 & 0.79 & $\mathrm{R}_{\mathrm{N}}=+9.4$ \\
$\mathrm{Si}(\mathrm{OH})_{4}$ & 18.2 & 0.71 & $\mathrm{R}_{\mathrm{Si}}=+5.6$ \\
$\mathrm{TIC}$ & 83 & 0.78 & $\mathrm{R}_{\mathrm{C}}=+1.28$ \\
$\mathrm{pH}{ }_{15}$ & -0.20 & 0.70 & 30 \\
$\mathrm{Chl}$ & -2.7 & 0.44 & \\
& & & \\
$\Delta \mathrm{TIC} / \Delta \mathrm{NO}_{3}=$ & $\mathrm{R}_{\mathrm{N}} / \mathrm{R}_{\mathrm{C}}=7.3 ; \Delta \mathrm{Si}(\mathrm{OH})_{4} / \Delta \mathrm{NO}_{3}=\mathrm{R}_{\mathrm{N}} / \mathrm{R}_{\mathrm{St}}=1.7$ \\
\end{tabular}

similar to those reported for other oceanic regions (Broecker 1974, Takahashi et al. 1985, Ríos et al. 1989), but the coefficients $R_{C}$ and $R_{N}$ obtained here are $8 \%$ lower than those given by Takahashi et al. (1985) and Ríos et al. (1989).

The distribution of chlorophyll a (chl a) showed a similar pattern. The highest values of chl a were in MW and a strong gradient was measured in the saline front, whereas low values were found in WW. To the east of SCW, the diatom Corethron criophilum was dominant, ranging from 50 to $93 \%$ of total phytoplankton abundance (Figueiras et al. 1994). However, at Stn 61, Phaeocystis spp. was relatively abundant ( $23 \%)$.

Plots of 'NO', nitrate and oxygen concentrations against salinity are shown in Fig. 3a for a single station. They indicate an almost linear relationship between these 2 variables, and also that a strong symmetrical relationship exists between the distribution of nitrate and oxygen. The slope of the regression line between oxygen and nitrate (Table 2 ) is similar to that used by Broecker (1974) to define the parameter ' $N O^{\prime}=\mathrm{O}_{2}+$ $\mathrm{R}_{\mathrm{N}} \times \mathrm{NO}_{3}$, which is independent of both photosynthetic activity and remineralization because oxygen variations are compensated by changes in nitrate. Minster \& Boulahdid (1987) also estimated similar values of $R_{N}=$ 9.3 in Atlantic seawater. As can be seen in the profiles shown in Fig. 3, 'NO' values remained constant and independent of salinity in the entire water column, except in the uppermost layer (0 to $20 \mathrm{~m}$ ) of eastern stations (Figs. 2 \& 3), where oxygen increases did not completely balance the observed nitrate deficit.

Other mixed stoichiometric parameters can be defined by following the same procedure. The parameters ' $\mathrm{NO}$ ', 'CAO' and ' $\mathrm{SiO}$ ' $\left[=\mathrm{O}_{2}+6 \times \mathrm{Si}(\mathrm{OH})_{4}\right]$ will be calculated by assuming the stoichiometric coefficients determined by linear regression shown in Table 2 . The effect that precipitation and redissolution of $\mathrm{CaCO}_{3}$
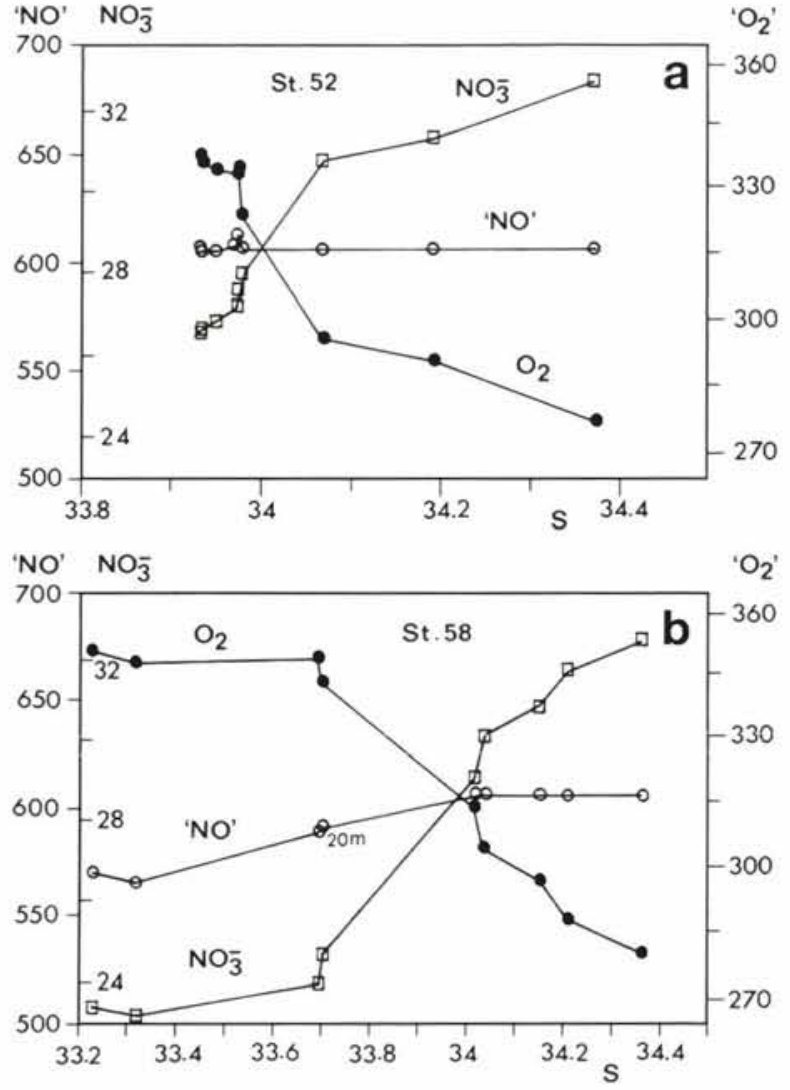

Fig. 3. Plots of oxygen, nitrates and 'NO' (all in $\mu \mathrm{mol} \mathrm{kg-1}$ ) versus salinity $(\%)$ at (a) $\operatorname{Stn} 52$ and (b) $\operatorname{Stn} 58$. The ratio between the scales of $\mathrm{O}_{2}$ and $\mathrm{NO}_{3}$ is $\mathrm{R}_{\mathrm{N}}$ (Table 2)

introduces in the variability of the carbonic system was corrected with the equation:

$$
{ }^{\prime} \mathrm{CAO}^{\prime}=\mathrm{O}_{2}+\mathrm{R}_{\mathrm{C}}\left[\mathrm{TIC}-1 / 2\left(\mathrm{Alk}+\mathrm{NO}_{3}\right)\right]
$$

where Alk is alkalinity (Broecker \& Peng 1982, Takahashi et al. 1985, Ríos et al. 1989). In the same way as at stations shown in Fig. 3, TIC was compensated by dissolved oxygen, generating an almost constant distribution of the parameter 'CAO' (Fig. 2) except in the surface layer of the easternmost stations. The homogeneity in 'NO' and 'CAO' (Fig. 2) distributions indicates that the 2 bodies of water previously considered, WW and MW, derive from a common body of water, being the MW of more recent and local origin.

The maximum decrease of salinity from WW to MW is $1.2 \times 10^{-3}$. This decrease means a dilution of WW with fresh water of $3.5 \%$. The concentration of nitrate expected from this dilution of WW (Table 1) should be $31.5 \mu \mathrm{mol} \mathrm{kg}{ }^{-1}$. However, the concentrations measured in MW are much lower $\left(23 \mu \mathrm{mol} \mathrm{kg}{ }^{-1}\right)$, suggesting that during the formation and evolution of MW, a consumption of nutrients and production of oxygen at the salinity minimum occurred in order to 
keep the 'NO' and 'CAO' parameters constant. Given that the distributions of TIC, nutrients and salinity showed a linear relationship, the consumption of nutrients is likely to take place where MW is formed. Thus, by relating ice melting and the corresponding decrease in nutrients, it is possible to estimate the amount of organic carbon produced per $\mathrm{m}^{2}$ that would be derived from the calculated consumption of nutrients.

In order to estimate the amount of fresh water of ice origin, we assume that the salinity decrease from WW was due only to ice melting and that the haline and chemical properties at $150 \mathrm{~m}$ depth (Table 1) were not affected by the melting of ice (Nelson et al. 1989). In order to avoid the vertical variability due to dynamic patterns (Pérez et al. 1994), the anomalies of physicochemical variables corresponding to WW were integrated down to $150 \mathrm{~m}$. The decrease in integrated salinity $(-\delta \mathrm{S})$ is proportional to the total amount of melting ice diluted in the water column,

$$
\delta \mathrm{S}=\frac{1}{150} \int_{0}^{150}\left(\mathrm{~S}-\mathrm{S}_{\mathrm{Ww}}\right) \mathrm{d} z
$$

where $\mathrm{S}_{W w}$ is the salinity of WW (Table 1 ). Then the height of the melted ice $\left(\mathrm{H}_{\mathrm{ice}}\right)$ or the quantity of fresh water per $\mathrm{m}^{2}$ is determined according to the equation

$$
\mathrm{H}_{\text {ice }}=150(-\delta \mathrm{S}) / \mathrm{S}_{\mathrm{wW}}
$$

Similarly, using the concentrations of TIC, nutrients and oxygen concentrations given in Table 1 as a reference for WW, and integrating the profile for each variable down to $150 \mathrm{~m}$, the nutrient deficit and associated oxygen increase was determined for the 30 sampling stations.

Integrated depletions for $\mathrm{NO}_{3}, \mathrm{TIC}$ and $\mathrm{O}_{2}$ (Fig. 4) were correlated and showed a similar distribution to that of salinity. Greater nutrient deficits were found in low salinity areas where MW is dominant. There is also a clear parallel with the distribution of integrated chlorophyll.

The linear regression between nitrate depletion $\left(\mathrm{NO}_{3}\right)$ and the equivalent height of melted ice is $\mathrm{r}^{2}=$ 0.74 with a slope of $0.28 \mathrm{~mol} \mathrm{NO}_{3} \mathrm{~m}^{-3}$. Although ammonium and nitrite values are not available to complete the inorganic nitrogen budget, the low concentrations measured in nearby regions (Bennekom et al. 1989, Nelson et al. 1989) suggest that they cannot explain by themselves the observed nitrate deficits. In a recent review, Tréguer \& Jacques (1992) reported significant subsurface values of ammonium, about $2 \mu \mathrm{M}$. However, the maximum values of ammonium integrated down to $150 \mathrm{~m}$ were about $0.8 \mu \mathrm{M}$.

The molar slope of the linear regression between TIC and $\mathrm{NO}_{3}$ was 7.6, close to a C:N molar ratio of 7.9 obtained by analysis of particulate organic nitrogen
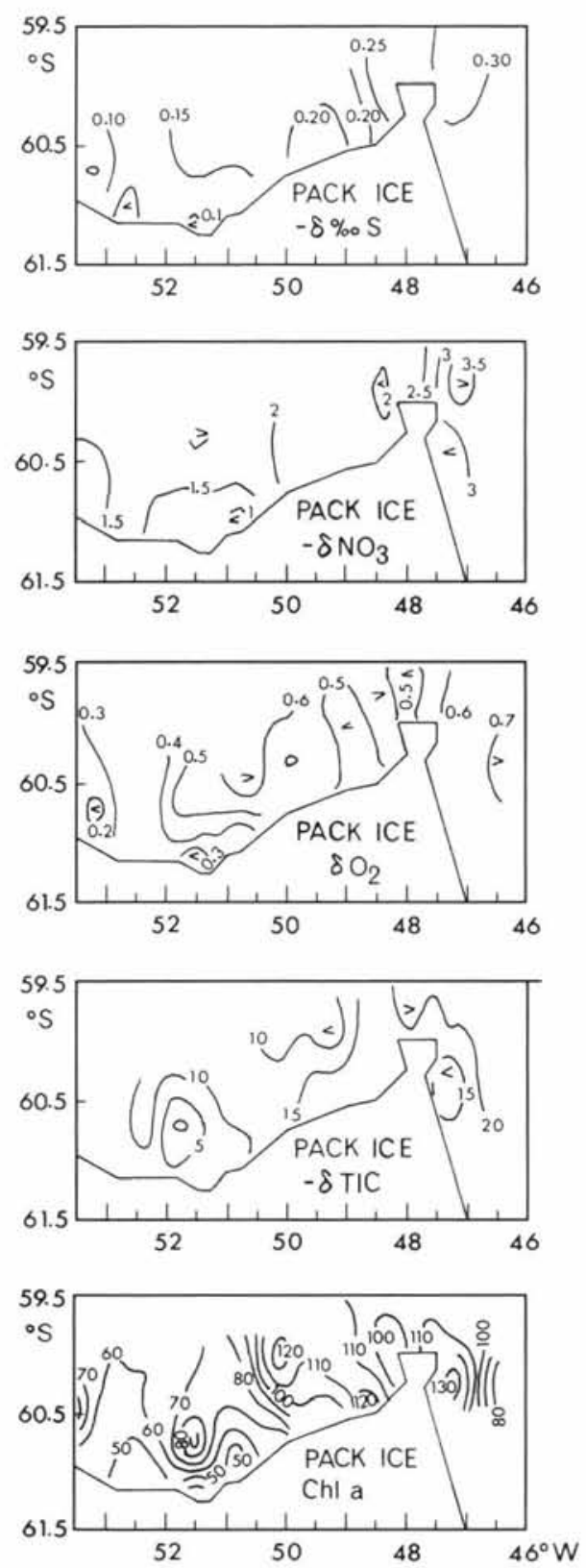

Fig. 4. Average anomalies of salinity $(\%)$, nitrates $\left(\mu \mathrm{mol} \mathrm{kg}{ }^{-1}\right)$, oxygen $\left(\mu \mathrm{mol} \mathrm{kg}{ }^{-1}\right)$ and TIC $\left(\mu \mathrm{mol} \mathrm{kg}{ }^{-1}\right)$. Average anomalies were calculated using Eq. (2). The distribution of integrated chlorophyll $\mathrm{a}\left(\mathrm{g} \mathrm{I} \mathrm{l}^{-1}\right)$ to $150 \mathrm{~m}$ is also given

(PON) and particulate organic carbon (POC) in ice samples (see below).

\section{Composition of particulate organic matter}

Fig. 5a shows the relationship between PON and chl $a$. A strong correlation was found $\left(\mathrm{r}^{2}=0.87\right)$ with a slope of $1.05 \pm 0.05 \mu \mathrm{g} \mathrm{chl} a \mu \mathrm{mol}^{-1} \mathrm{PON}$. However, the 

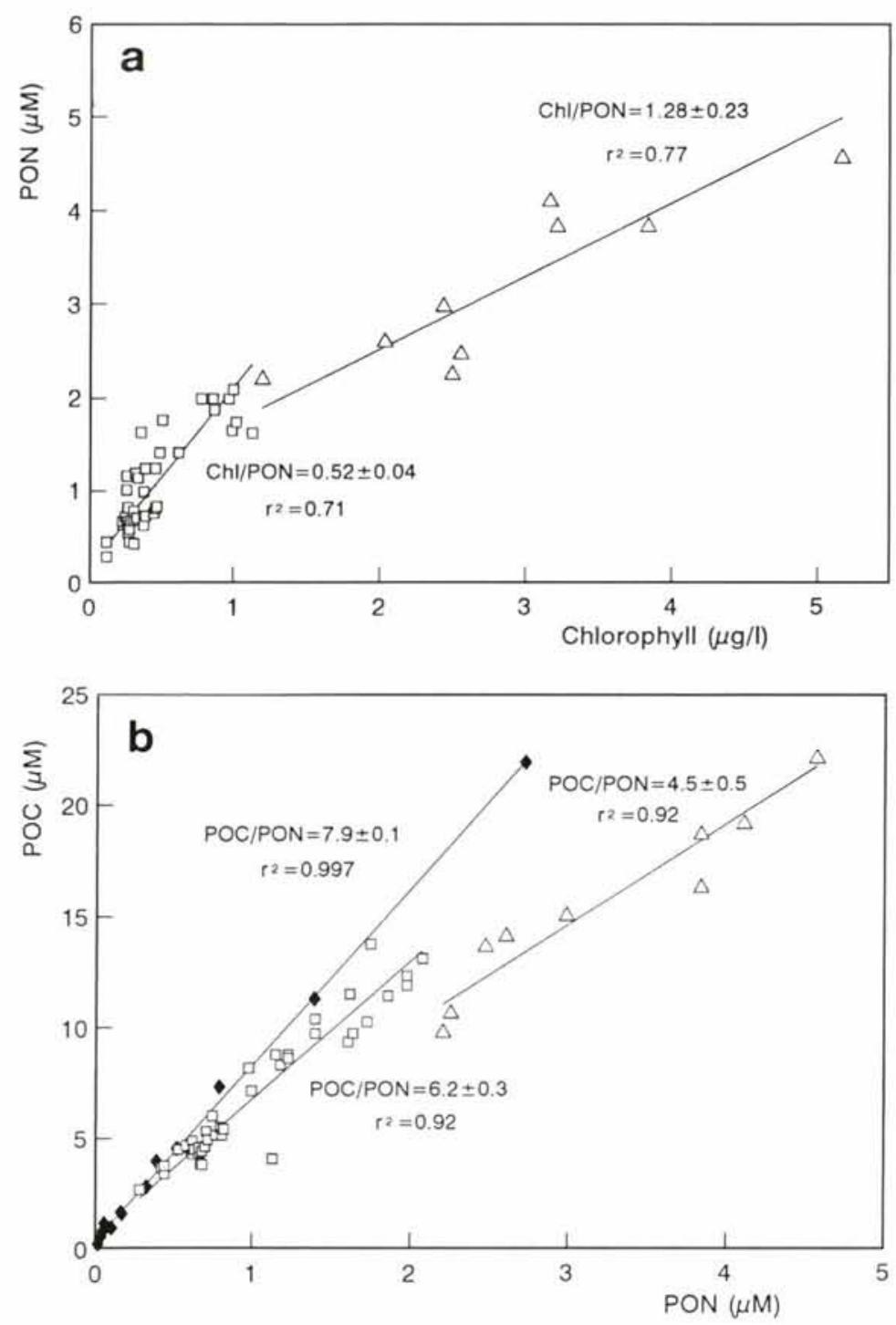

Fig. 5. Relation between (a) PON and chlorophyll and (b) POC and PON in suspended organic matter in seawater. $(\bullet)$ Pack-ice sample, value $\times 100$

data are distributed in 2 groups, probably related to different populations inhabiting the 2 bodies of water. The highest chlorophyll values were found in meltwaters with salinities lower than $33.9 \%$ (Fig. 2). The slope of the regression is $1.28 \pm 0.23 \mu \mathrm{g} \mathrm{chl} a \mu \mathrm{mol}^{-1}$ PON (C: chl a ratio for MW is about 42), close to that of Dortch (1987). This gave a ratio of $1.8 \mu \mathrm{g} \mathrm{chl} \mathrm{a} \mu_{\mathrm{mol}^{-1}}$ protein nitrogen, equivalent to $1.44 \mu \mathrm{g} \mathrm{chl} \mathrm{a} \mathrm{mol}^{-1}$ PON. At salinities higher than $33.9 \%$, characteristic of Weddell Water, low PON and chl a values are found, and the slope of the relationship falls to $0.52 \pm 0.04 \mu \mathrm{g}$ chl $a \mu \mathrm{mol}^{-1}$ PON (C: chl a ratio about 143), which suggests a significant contribution of non-photosynthetic particulate material. As a first approximation, the value of the $y$-intercept in these regressions can be used as an estimator of the amount of detrital, or at least non-chlorophyllous, particulate material. At stations dominated by MW and with moderate chl $a$ concentrations, the $y$-intercept is about $1.2 \mu \mathrm{mol} \mathrm{PON} \mathrm{l}^{-1}$ (about $5.5 \mu \mathrm{mol}$ POC $1^{-1}$ ), indicating that $35 \%$ of the particulate matter is non-chlorophyllous. At stations dominated by Winter Weddell Water, with low chl $a$, the $y$-intercept is about $0.1 \mu \mathrm{mol} \mathrm{PON} 1^{-1}$, equivalent to $0.6 \mu \mathrm{mol} \mathrm{POC} 1^{-1}$ which indicates that the fraction of non-chlorophyllous particulate carbon is about $9 \%$ of average POC.

The relationship between POC and PON shows a similar behavior (Fig. 5b). Two clusters of data are clearly differentiated by their PON content and C:N ratios. Samples from melt-water form a group characterized by high PON values and a mean $\mathrm{C}: \mathrm{N}$ ratio of 4.5, which indicates vigorously growing phytoplankton and/or high bacterial biomass. The low POC levels associated with samples from WW with low chlorophyll levels result in a $\mathrm{C}: \mathrm{N}$ ratio of 6.2 .

The analysis of POM made on 14 ice samples (Fig. 5b) showed some samples with very high POC contents and a C:N ratio of 7.9, close to that obtained from TIC and $\mathrm{NO}_{3}$ in the water column.

\section{Phytoplankton biomass and nutrient deficit}

A significant difference was found between the nutrient deficit integrated over the upper layer and integrated chlorophyll concentration. The average chlorophyll concentration integrated from surface to $150 \mathrm{~m}$ (Fig. 4) in the area was $75 \mathrm{mg} \mathrm{m}^{-2}$ with minimum and maximum values of 40 and $130 \mathrm{mg}$ $\mathrm{m}^{-2}$ corresponding to homogeneous WW and the lens of MW, respectively. Based on the mean POC, PON and chl $a$ values, the chl a:PON ratio was

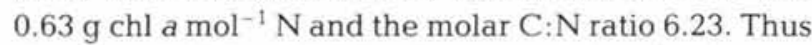
the mean PON and POC values are 120 and $748 \mathrm{mmol}$ $\mathrm{m}^{-2}$, respectively. These values contrast with the integrated deficit values of $\mathrm{NO}_{3}{ }^{-}$and TIC of 300 and 2100 $\mathrm{mmol} \mathrm{m} \mathrm{m}^{-2}$, respectively (Table 3 ). So, the amount of particulate matter present in the water only accounts for $35 \%$ of nutrient depletion, whereas about $65 \%$ of the nutrients consumed by photosynthesis was either exported out of the upper layer by grazing and sinking (El-Sayed 1984, Holm-Hansen 1985, Smith \& Nelson 1986, Jacques \& Panouse 1989, 1991, Nelson et al. 1989), incorporating the pack-ice microalgae, or made 
Table 3. Mean of integrated anomalies to $150 \mathrm{~m}$ for the 24 stations on the BIOMASS IV cruise carried out at the ice-edge $\left(\approx 21600 \mathrm{~km}^{2}\right)$ for salinity $\left(\mathrm{g} \mathrm{m}^{-2}\right)$, oxygen, $\mathrm{NO}_{3}-\mathrm{Si}(\mathrm{OH})_{4}, \mathrm{TIC}$, ' $\mathrm{NO}$ ', 'CAO', and 'SiO'. Height of ice $(0.80 \mathrm{~m})$ was made equivalent to the salinity decrease in the water column (see Eq. 3). From the stoichiometric ratio shown in Table 2 and the atomic weight of $\mathrm{C}$, these integrated nutrient anomalies are converted to biomass in $\mathrm{g} \mathrm{C} \mathrm{m}^{-2}$

\begin{tabular}{|c|c|c|c|c|c|c|c|c|}
\hline & $\delta \mathrm{S}$ & $\delta \mathrm{O}_{2}$ & $\delta \mathrm{NO}_{3}$ & $\delta \mathrm{Si}(\mathrm{OH})_{4}$ & $\delta \mathrm{TIC}$ & $\delta^{\prime} \mathrm{NO}^{\prime}$ & $\delta^{\prime} \mathrm{CAO}^{\prime}$ & $\delta^{\prime} \mathrm{SiO}^{\prime}$ \\
\hline Anomaly & -27 & 3150 & -300 & -570 & -2100 & -240 & -330 & -330 \\
\hline Biomass $\left(\mathrm{g} \mathrm{C} \mathrm{m}^{-2}\right)$ & & 29 & 26 & 29 & 25 & & & \\
\hline
\end{tabular}

up the pool of dissolved organic matter. The ratio between the amount of particulate matter and nutrient depletion is slightly higher in the homogenous WW (about $40 \%$ ) than in MW (about $25 \%$ ), due in part to differences in the ratios PON: $\mathrm{chl} a$ and POC:PON.

The calculated silicate deficit was about $570 \mathrm{mmol}$ $\mathrm{m}^{-2}$ (Table 3). The $\delta \mathrm{Si}(\mathrm{OH})_{4}: \delta \mathrm{TIC}$ estimated by average anomalies $(570 / 2100)$ is about 0.27 , and that obtained by regression of integrated anomalies (Fig. 4) is $0.26 \pm 0.04(\mathrm{r}=0.73, \mathrm{n}=22)$, within the ranges of $\mathrm{Si}: \mathrm{C}$ ratios given by Nelson et al. (1989) and Tréguer et al. (1988) for southern seas. Although we did not measure biogenic silica, it can be estimated by using the obtained $\mathrm{Si}: \mathrm{C}$ ratio. This estimation yielded a concentration of biogenic silica of $202 \mathrm{mmol} \mathrm{m}^{-2}$, which is very close to the $200 \mathrm{mmol} \mathrm{m}^{-2}$ reported by Nelson et al. (1989) in a $150 \mathrm{~m}$ water column in the Weddell Sea close to the Marginal Ice Zone (MIZ) during March 1986. The regression between silicate depletion and chl $a$ gives a slope of $4.5 \pm 0.5(\mathrm{r}=0.5)$. Nelson et al. (1987) reported similar values of 4.15 for the silica:chlorophyll ratio in particulate matter.

Fig. 6 shows the relationship between integrated $\mathrm{NO}_{3}{ }^{-}+\mathrm{NO}_{2}{ }^{-}$and $\mathrm{O}_{2}$ data published by Alvarez (1989) for samples obtained during the ANTARTIDA 8611 expedition carried out in January 1987 in the same area, but when the ice-edge was located further to the south and the pack-ice melting had finished. $\mathrm{Ni}$ trate concentrations were lower than those observed here, while the oxygen gradient was slightly greater. In the same figure, a line representing the theoretical oxygen was drawn taking into account the average value of nitrate and oxygen of WW located between 150 and $250 \mathrm{~m}$ depth during the same cruise. When the observed oxygen concentration were close to saturation, oxygen concentrations were lower than those estimated from nitrate values. However, oxygen values found during the BIOMASS IV and ANTARTIDA 8611 cruises rarely exceed saturation values (Foster \& Carmack 1976). The lowest nitrate concentration was found at the surface during both cruises and was associated with oxygen values close to saturation. Average anomalies of nitrate and oxygen in the upper $150 \mathrm{~m}$ water column calculated from Al-

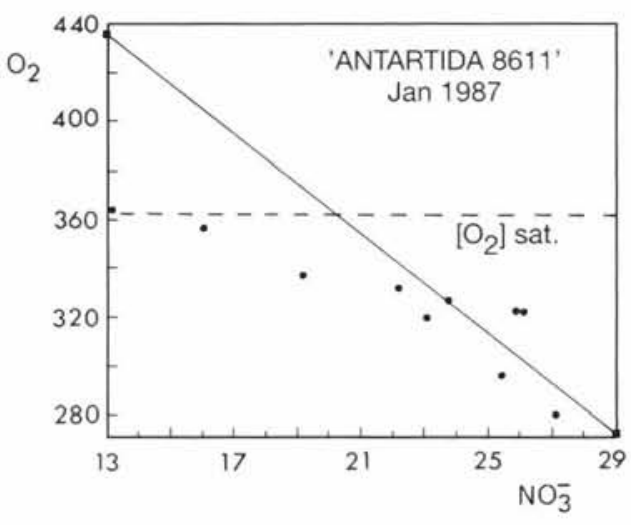

Fig. 6. Relation between integrated average nitrates and dissolved oxygen (in $\mu \mathrm{M}$ ) in samples from the Orkney Island area (Alvarez 1989). ( $\longrightarrow$ ) Reference line taking into account the nitrate of intermediate Water (150 to $250 \mathrm{~m}$ ) and stoichiometric slope; (- - ) oxygen saturation for salinity of $34 \%$

varez's data gives an average nitrate deficit of $4.2 \mu \mathrm{M}$ ( $630 \mathrm{mmol} \mathrm{m}^{-2}$ ) and a $23 \%$ oxygen loss with regard to the oxygen potentially produced by the consumption of nitrate.

Considering the stoichiometric ratios obtained here (Table 2), the pattern showed by the deficits of $\mathrm{NO}_{3}$, TIC and $\mathrm{Si}(\mathrm{OH})_{4}$ and the increase in $\mathrm{O}_{2}$ are in close agreement (Table 3 ) yielding the same primary production estimates. The potential primary production rates estimated from these average nutrient deficits was about $34 \mathrm{~g} \mathrm{C} \mathrm{m}^{-2}$ when pack-ice of $1 \mathrm{~m}$ depth was melted. Taking into account an average depth of packice of $1.6 \pm 0.5 \mathrm{~m}$ (Sullivan et al. 1988), a production of $54 \mathrm{~g} \mathrm{C} \mathrm{m}^{-2}$ results due to the melting of pack-ice when the ice-edge retreats. These results are in agreement with those calculated here using data from the ANTARTIDA 8611 expedition (Alvarez 1989).

\section{DISCUSSION}

Deficits of $\mathrm{NO}_{3}$, TIC and $\mathrm{Si}(\mathrm{OH})_{4}$ along with $\mathrm{O}_{2}$ increases in the MIZ reflect an intense biological activity which takes place over the same time scale as pack- 
ice melting. The ratios between the deficits of the different nutrients and the increases in oxygen allow us to estimate the averaged stoichiometric equation of the synthesis of organic matter. This equation is similar to that given by previous authors (Takahashi et al. 1985 , Ríos et al. 1989) suggesting that the origin of the observed nutrient deficits derives from the synthesis of organic matter.

Our observations show that increasing stability due to ice melting gives rise to higher nutrient removal associated with moderate accumulation of phytoplankton biomass as has been previously reported (El-Sayed \& Taguchi 1981, Holm-Hansen 1985, Bennekom et al. 1989). In addition, we found 4 results of relevance: (1) the 2 water masses observed near the pack-ice (MW and WW) had the same origin, MW being a modification of WW by dilution with melt-water; (2) high linear correlations between nutrient distributions and salinity were observed; (3) the observed oxygen values were rarely higher than saturation, when high nutrient depletion occurs; and (4) the ratio $\delta \mathrm{TIC}: \delta \mathrm{NO}_{3}$ is close to the $\mathrm{C}: \mathrm{N}$ ratio found in the sampled algae in the pack-ice, which is significantly higher than those found in the water column.

The exact location where the nutrients are taken up by phytoplankton is difficult to assess given their quasi-conservative behaviour. If nutrients were depleted in the water column as in saline frontal systems of temperate regions, a deep oxygen and chl a maximum should be generated and, as a consequence, the distributions of nutrients and oxygen would not be correlated with salinity. If the chlorophyll distribution would show moderate correlation with salinity as is the case here, nutrient uptake might be linearly related to saline variability and, therefore, a nutrient pattern like the one described here would be likely to occur. However, this possible model would not explain results (3) and (4).
An alternative model would be that nutrient depletion in the pack-ice occurs on similar time scales as the melting process. This possibility would explain the high linear correlation observed between nutrients and salinity, resulting from nutrient decreases generated in the pack-ice. Therefore, the fact that photosynthetic activity was taking place close to the atmosphere-water boundary would explain the oxygen losses from the seawater when their values were close to saturation and, also, the agreement in the $\mathrm{C}: \mathrm{N}$ ratio in nutrient depletions and ice-biomass.

This last model would mean that a large part of nutrient consumption had been carried out by the high biomass of algae associated with ice during the spring (Ackley et al. 1979, Palmisano \& Sullivan 1983, Garrison et al. 1989) over temporal and spatial scales close to the process of ice melting, or alternatively, by ice algae released to the water after melting. Recently, Arrigo et al. (1993) have shown very high values of chlorophyll in the thick platelet layer (between 280 and $1090 \mathrm{mg} \mathrm{m}^{-2}$ ) in McMurdo Sound between the end of October to the beginning of December, with a strong increase of algal biomass occurring in the last fortnight of November. In addition, Prego (1991) reported values of total organic carbon (TOC) in the MW which were 3 times higher than those measured in WW. High values of TOC in MW $(>150 \mu \mathrm{M})$ would result from processes of degradation and/or exudation of POC associated with an important pool of biomass. It does not appear to be possible that the phytoplankton present exclusively in the water column could account for these high TOC levels, but that ice-algae are most likely to be responsible for this release of TOC.

The average primary production estimated for the MIZ was approximately $54 \mathrm{~g} \mathrm{C} \mathrm{m}^{-2}$. This result is similar regardless of whether $\mathrm{NO}_{3}, \mathrm{TIC}, \mathrm{Si}(\mathrm{OH})_{4}$ or $\mathrm{O}_{2}$ anomalies are used for the calculations, and is also similar to values estimated with data from the ANTAR-

Table 4. Mean values of selected phytoplankton biomass in 3 marginal ice zones of the Southern Ocean

\begin{tabular}{|c|c|c|c|c|c|c|}
\hline Region & $\begin{array}{c}\text { Chl } a \\
\left(\mathrm{~g} \mathrm{~m}^{-3}\right)\end{array}$ & $\begin{array}{l}\text { POC } \\
\qquad(\mu \mathrm{mol} \mathrm{ks}\end{array}$ & $\underset{\left.g^{-1}\right)}{\text { PON }}$ & $\begin{array}{l}\mathrm{C}: \mathrm{chl} a \\
\left(\mathrm{~g} \mathrm{~g}^{-1}\right)\end{array}$ & $\begin{array}{c}\mathrm{C}: \mathrm{N} \\
\left(\mathrm{mol} \mathrm{mol}^{-1}\right)\end{array}$ & Source \\
\hline Weddell (Feb-Mar 1977) & & & & & & El-Sayed \& Taguchi (1981) \\
\hline North and Central & 0.06 & 2.2 & 0.25 & 416 & 9.1 & \\
\hline Southern & 1.56 & 4.4 & 0.63 & 35 & 7.0 & \\
\hline Weddell-Scotia (Nov 1983) & 4.0 & 10.6 & 1.5 & 31.8 & 7.1 & Nelson et al. (1987) \\
\hline Western Ross (Jan-Feb 1983) & 2.9 & 33.2 & 5.6 & 138 & 5.9 & Nelson \& Smith (1986) \\
\hline West Weddell (Mar 1986) & 0.38 & 3.6 & 0.46 & 114 & 7.8 & Nelson et al. (1989) \\
\hline Indian Sector (Jan-Feb 1984) & 0.21 & 7.2 & 0.97 & 410 & 7.3 & Tréguer et al. (1988) \\
\hline Weddell (1989) & & & & & & This study \\
\hline Melting Water & 3.12 & 16.2 & 3.33 & 43 & 4.9 & \\
\hline Weddell Water & 0.47 & 7.1 & 1.15 & 120 & 6.2 & \\
\hline
\end{tabular}


TIDA 8611 cruise. Jennings et al. (1984), estimating primary production using a similar method similarly based on nutrient depletion, reported that, during a period of 60 to $90 \mathrm{~d}$, nutrients decreased by 300,27 and $850 \mathrm{mmol} \mathrm{m}^{-2}$ for $\mathrm{NO}_{3}, \mathrm{PO}_{4} \mathrm{H}$ and $\mathrm{Si}(\mathrm{OH})_{4}$ respectively in the Weddell Sea. The decrease in $\mathrm{NO}_{3}$ coincided with that obtained here, while the silicate decrease was $33 \%$ lower.

Assuming a mean gross productivity of about $1.5 \mathrm{~g} \mathrm{C}$ $\mathrm{g}^{-1} \mathrm{chl} \mathrm{a} \mathrm{h}^{-1}$ for the phytoplankton in Antarctic open water (Holm-Hansen 1985, Lancelot \& Mathot 1989, Figueiras et al. 1994), and a phytoplankton biomass given by the average measured $\mathrm{chl} a\left(75 \mathrm{mg} \mathrm{chl} a \mathrm{~m}^{-2}\right)$, the carbon take up in the water column was estimated to be $112 \mathrm{~g} \mathrm{C} \mathrm{m}^{-2} \mathrm{yr}^{-1}$. Then, the production calculated by nutrient depletion in the MIZ due to ice melting represents half of that value, as was found in the global estimate by Smith \& Nelson (1986).

In the Weddell Sea, Smith \& Nelson (1990) calculated new production in the MIZ to be ca $49 \mathrm{~g} \mathrm{C} \mathrm{m}^{-2}$ $\mathrm{yr}^{-1}$ from November to March. Since estimated nitrate depletion represents integrated new production, the MIZ must be considered an important area for new production (Smith 1991).

The amounts of particulate matter and the ratios between the concentrations of chl $a, \mathrm{POC}$ and PON are closely related to the physical environment. The low $\mathrm{C}: \mathrm{chl} a$ and $\mathrm{C}: \mathrm{N}$ ratios in MW suggest that environmental conditions were physiologically favorable for phytoplankton growth or that bacterial biomass made up a significant fraction of the total particulate material. El Sayed \& Taguchi (1981) found a very similar pattern in 2 regions of the Weddell Sea with different hydrographic characteristics. They found different $\mathrm{C}: \mathrm{N}$ and $\mathrm{C}: \mathrm{chl} a$ ratios for 2 regions with different depth of the euphotic zone (Table 4). In areas with shallower euphotic zones $(20 \mathrm{~m})$, the C:chl $a$ and C:N ratios were 35 and 7 , respectively, whereas in areas with a thicker euphotic layer $(57 \mathrm{~m})$, these ratios were 416 and 9.1 .

More recently Nelson et al. (1987), studying particulate matter in this area close to the MIZ in spring, found similar results to those shown here in an MW lens, although their $\mathrm{C}: \mathrm{N}$ ratios were higher (Table 4). By the end of summer in the MIZ situated in the western Weddell Sea, Nelson et al. (1989) reported POC, PON and chl $a$ values similar to those found in the bodies of water characterized as WW. In the MIZ of the Ross Sea, Nelson \& Smith (1986) obtained low C:N ratios, which are slightly higher than those shown here. The ratio between depleted $\mathrm{Si}(\mathrm{OH})_{4}$ and $\mathrm{NO}_{3}$ obtained here $(2.9 \pm 0.5, r=0.60)$ is similar to those obtained by Le Jehan \& Tréguer (1983) in the Indian Sector $(0.8$ to 4$)$. The values of the ratio between depleted $\mathrm{Si}(\mathrm{OH})_{4}$ and TIC $(0.26)$ could be compared to the biogenic $\mathrm{Si}: \mathrm{C}$ ratio. In the Indian Sector Tréguer et al. (1988) show a biogenic $\mathrm{Si}: \mathrm{C}$ of 0.19 , while in the Weddell Sea during spring, Nelson et al. (1987) obtained a ratio of 0.13 . During late summer in the Weddell Sea, Nelson et al. (1989) reported a Si:C ratio about 0.51 .

These results indicate that 2 different environments exist close to the MIZ. These environments have differing physico-chemical characteristics and a distinctive chemical composition of particulate matter, shaping a small-scale structure similar to those described by Sullivan et al. (1988) from satellite imagery. The strong photosynthetic activity measured in regions influenced by ice melting characterized the distribution of nutrients and oxygen, making up an important fraction of the primary production in the MIZ. This production represents a large fraction of the new production generated in the area, and occurs over similar spatial and temporal scales as the process of ice melting. The high levels of TOC (Prego 1991) and the large proportion of non-photosynthetic particulate material in the water column suggest the predominance of heterotrophic activity in the water column.

Acknowledgements. This study was carried out as a collaborative project between the Institute of Ecology (Polish Academy of Sciences) and Consejo Superior de Investigaciones Cientificas, and was supported by project number MAR88245 of Comision Interministerial de Ciencia y Tecnologia. Thanks are due to P. J. Wangersky, M. Estrada, E. Fernández and $F$. Fraga for their critical reviews of an earlier draft. Dr R. Prego analyzed nitrates and silicates, and Mr Penín ran the particulate organic matter analysis.

\section{LITERATURE CITED}

Ackley, S. F., Buck, K. R., Taguchi, S. (1979). Standing crop of algae in the sea ice of the Weddell Sea region. Deep Sea Res. 26: 269-282

Alexander, V., Niebauer, H. J. (1981). Oceanography of the Bering Sea ice edge zone in spring. Limnol. Oceanogr. 26: $1111-1125$

Alvarez, A. (1989). Parametros oceanográficos. Resultados de la campana 'ANTARTIDA 8611'. Publicaciones Especiales Instituto Español de Oceanografia, no. 2, Madrid, p. 175-209

Arrigo, K. R., Robinson, D. H., Sullivan, C. W. (1993). A high resolution study of the platelet ice ecosystem in McMurdo Sound, Antarctica: photosynthetic and bio-optical characteristics of a dense microalgal bloom. Mar. Ecol. Prog. Ser. 98: 173-185

Baar, H. J. W., Buma, A. G. J., Jacques, G., Nolting, R. F., Tréguer, P. (1989). Trace metals - iron and manganese effects on phytoplankton growth. The Expedition Antarktis VII/3 (EPOS LEG 2) of RV 'Polarstern' in 1988/89. In: Hempel, 1., Schalk, P. H., Smetacek, V. (eds.) Reports on polar research 65/89. Alfred Wegener Inst. for Polar and Marine Research, Bremerhaven, p. 34-43

Bennekom, J. van, Estrada, M., Goeyens, L., Magas, B., Masson, A., Morvan, J., Tréguer, P., Svansson, A., Veth, C. (1989). Uptake and regeneration of nitrogen, silica and 
phosphorous. In: Hempel, I., Schalk, P. H., Smetacek, V. (eds.) Reports on polar research 65/89. Alfred Wegener Inst. for Polar and Marine Research, Bremerhaven, p. 56-60

Broecker, W. S. (1974). 'NO', a conservative water-mass tracer. Earth Planet. Sci. Lett. 23: 100-107

Broecker, W. S., Peng, T. H. (1982). Tracers in the sea. Lamont-Doherty Geological Observatory, New York

Carritt, D. E., Carpenter, J. H. (1966). Comparison and evaluation of currently employed modifications of the Winkler method for determining dissolved oxygen in sea water. J. mar. Res. 24: 286-318

Deacon, G. E. R., Foster, T. D. (1977). The boundary region between the Weddell Sea and Drake Passage currents. Deep Sea Res. 24: 505-510

Deacon, G. E. R., Moorey, J. A. (1975). The boundary region between currents from the Weddell Sea and Drake Passage. Deep Sea Res. 22: 265-268

Dortch, Q. (1987). The biochemical composition of plankton in a surface chlorophyll maximum. Deep Sea Res. 34: $705-712$

El-Sayed, S. Z. (1984). Productivity of Antarctic waters - a reappraisal. In: Holm-Hansen, O., Bolis, L., Gilles, R. (eds.) Marine phytoplankton and productivity. Springer-Verlag, Berlin, p. 19-34

El-Sayed, S. Z., Taguchi, S. (1981). Primary production and standing crop of phytoplankton along the ice-edge in the Weddell Sea. Deep Sea Res. 28A(9): 1017-1032

Falkowski, P., Kiefer, D. A. (1985). Chlorophyll a fluorescence in phytoplankton: relationship to photosynthesis and biomass. J. Plankton Res, 7: 715-731

Figueiras, F. G., Pérez, F. F., Pazos, Y., Ríos, A. F. (1994). Light and productivity of antarctic phytoplankton during austral summer in an ice edge region in the Weddell-Scotia Sea. J. Plankton Res. 16: 233-253

Foster, T. D., Carmack, E. C. (1976). Frontal zone mixing and Antarctic Bottom Water formation in the southern Weddell Sea. Deep Sea Res. 23: 301-317

Fraga, F. (1976). Distribución del carbono organico particulado en la región del afloramiento del NW de Africa y su relación con el nitrógeno particulado. I Marzo 1973. Res. Exp. Cient. B/O Cornide de Saavedra 10:51-77

Garrison, D. L., Close, A. R., Reimnitz, E. (1989). Algae concentrated by frazil ice: evidence from laboratory experiments and field measurements. Antarctic Sci. 1(4): $313-316$

Hansen, H. P., Grasshoff, K. (1983). Automated chemical analysis. In: Grasshoff, K., Eurhardt, M., Kremling, K. (eds.) Methods of seawater analysis, 2nd edn. Verlag Chemie, Weinheim, p. 368-376

Holm-Hansen, O. (1985). Nutrient cycles in antarctic marine ecosystems. In: Siegfried, W. R., Condy, P. R., Laws, R. M. (eds.) Antarctic nutrient cycles and food webs. SpringerVerlag, Berlin, p. 6-10

Holm-Hansen, O., Lorenzen, C. J., Holmes, R. W., Strickland, J. D. H. (1965). Fluorimetric determination of chlorophyll. J. Cons, perm. int. Explor. Mer 30:3-15

Jacques, G., Panouse, M. (1991). Biomass and composition of size fractionated phytoplankton in the Weddell-Scotia Confluence area. Polar Biol. 11: 315-328

Jacques, G., Panouse, M. (1989). Phytoplankton biomass distribution. The Expedition Antarktis VII/3 (EPOS LEG 2) of RV 'Polarstern' in 1988/89. In: Hempel, I., Schalk, P. H., Smetacek, V. (eds.) Reports on polar research 65/89. Alfred Wegener Inst. for Polar and Marine Research, Bremerhaven, p. 61-68

Jennings, J. C. Jr, Gordon, L. I., Nelson, D. M. (1984). Nutrient depletion indicates high primary productivity in the Weddell Sea. Nature 309: 51-54

Lancelot, C., Mathot, S. (1989). Phytoplankton: photosynthesis, growth and respiration. The Expedition Antarktis VII/3 (EPOS LEG 2) of RV 'Polarstern' in 1988/89. In: Hempel, I., Schalk, P. H., Smetacek, V. (eds.) Reports on polar research 65/89. Alfred Wegener Inst. for Polar and Marine Research, Bremerhaven, p. 78-86

Le Jehan, Tréguer, P. (1983). Uptake and regeneration $\Delta \mathrm{Si} / \Delta \mathrm{N} / \Delta \mathrm{P}$ ratios in the Indian Sector of the Southern Ocean. Polar Biol. 2: 127-136

Mehrbach, C., Culberson, C., Hawley, J. E., Pytkowicz, R. M. (1973). Measurements of the apparent dissociation constants of carbonic in seawater at atmospheric pressure. Limnol. Oceanogr. 18: 897-907

Minster, J.-F., Boulahdid, M. (1987). Redfield ratios along isopycnal surfaces - a complementary study. Deep Sea Res. 34(12): 1981-2003

Mouriño, C., Fraga, F. (1985). Determinación de nitratos en agua de mar. Invest. Pesq. 49: 81-96

Nelson, D. M., Smith, W. O. Jr (1986). Phytoplankton bloom dynamics of the western Ross Sea ice-edge. II. Mesoscale cycling of nitrogen and silicon. Deep Sea Res. 36(2): 191-209

Nelson, D. M., Smith, W. O., Gordon, L. 1., Huber, B. A. (1987). Spring distributions of density, nutrients and phytoplankton biomass in the ice-edge of the Weddell/Scotia Sea. J. geophys. Res. 92: 7181-7190

Nelson, D. M., Smith, W. O., Muench, R. D., Gordon, L. 1., Sullivan, C. W., Husby, D. M. (1989). Particulate matter and nutrient distribution in the ice-edge zone of the Weddell/Scotia: relationship to hydrography during late summer. Deep Sea Res, 36(2): 191-209

Palmisano, A. C., Sullivan, C. W. (1983). Sea ice microbial communities of ice algae in McMurdo Sound, Antarctica in 1980. Polar Biol. 2: 171-177

Pérez, F. F., Fraga, F. (1987a). The pH measurements in seawater on NBS scale. Mar. Chem. 21: 315-327

Pérez, F. F., Fraga, F. (1987b). A precise and rapid analytical procedure for alkalinity determination. Mar. Chem. 21: $169-182$

Pérez, F. F., Tokarczyk, R., Figueiras, F. G., Ríos, A. F. (1994). Water masses and phytoplankton biomass distribution during summer in the Weddell Sea Marginal Ice Zone. Oceanol. Acta 17: in press

Prego, R. (1991). Total organic carbon in the sea-ice zone between Elephant Island and South Orkney Islands at the start of the austral summer (1988-89). Mar. Chem. 35: $189-197$

Ríos, A. F., Fraga, F., Pérez, F. F. (1989). Estimation of coefficients for the calculation of 'NO', 'PO', and ' $\mathrm{CO}$ ', starting from the elemental composition of natural phytoplankton. Scientia mar. 53: 779-784

Sakshaug, E., Holm-Hansen, O. (1984). Factors governing pelagic production in polar oceans. In: Holm-Hansen, O., Bolis, L., Gilles, R. (eds.) Marine phytoplankton and productivity. Springer-Verlag, Berlin, p, 1-18

Smith, W. O. (1991). Nutrient distributions and new production in polar regions: parallels and contrasts between Arctic and Antarctic. Mar. Chem. 35: 245-257

Smith, W. O., Nelson, D. M. (1986). Importance of ice edge phytoplankton production in the Southern Ocean. BioSci. 36: $251-257$

Smith, W. O., Nelson, D. M. (1990). Phytoplankton growth and new production in the Weddell Sea ice zone in the austral spring and autumn. Limnol. Oceanogr. 35(4): $809-821$ 
Sullivan, C. W., McClain, C. R., Comiso, J. C., Smith, W. O. (1988). Phytoplankton standing crops within an antarctic ice edge assessed by satellite remote sensing. J. geophys. Res. 93(C20): 12487-12498

Takahashi, T., Broecker, W. S., Langer, S. (1985). Redfield ratio based on chemical data from isopycnal surfaces. J. geophys Res. 90: 6907-6924

Tréguer, P., Gueneley, S., Kamatani, A. (1988). Biogenic silica and particulate organic matter from the Indian sector of

This article was presented by P. J. Wangersky (Senior Editorial Advisor), Victoria, B.C., Canada the Southern Ocean. Mar. Chem. 23: 167-180

Tréguer, P., Jacques, G. (1986). L'Océan Antarctique. La Recherche 176: 746-755

Tréguer, P., Jacques, G. (1992). Dynamics of nutrients and phytoplankton, and fluxes of carbon, nitrogen and silicon in the Antarctic Ocean. Polar Biol. 12: 149-162

Yentsch, C. S., Menzel, D. W. (1963). A method for the determination of phytoplankton chlorophyll and phaeophytin by fluorescence. Deep Sea Res. 10: 221-231

Manuscript first received: October 15, 1993

Revised version accepted: June 16, 1994 